\title{
Impact of Regular Consumption of the Main Ivorian Traditional Dishes on Blood Biochemical Parameters and Certain Nutrition Regulators: Cases in Growing Rats (Rattus norvegicus)
}

\author{
Adou Koffi Kunindjani ${ }^{1 \star}$, Vincent Kadjo $^{2}$, Jean Brice Gbakayoro ${ }^{1}$, Abou Joel Ladry Okon ${ }^{3}$, Kouakou Brou $^{1}$ \\ ${ }^{1}$ Laboratory of Nutrition and Food Safety, Department of Food Science and Technology, University Nangui Abrogoua \\ Abidjan, Côte d'Ivoire \\ ${ }^{2}$ Department of Animal Biology, UFR Biological Sciences, University Péléforo Gon Coulibaly of Korhogo, \\ Korhogo, Côte d'Ivoire \\ ${ }^{3}$ Laboratory of Histology-embryology and cytogenetics, UFR Medical sciences, University Felix Houphouet Boigny \\ Abidjan, Côte d'Ivoire \\ ${ }^{*}$ Corresponding author: Kunindjani [AT] yahoo.fr
}

\begin{abstract}
The aim of this work was to assess the impact of regular consumption of Ivorian traditional dishes on growing wistar rats. Thus, a nutrition test was carried out with 40 rats divided into 5 groups of 8 rats. The rats in one batch were fed with an Ivorian traditional dish and the control rats ingested the control dish for 22 days. At the end of the experiment, biological examinations allowed us to assess the state of the body's functioning. The histopathology of the liver and kidney of the rats was performed. The blood sugar levels of the rats who consumed the Ivorian traditional dishes varied between $0.79 \mathrm{~g} / \mathrm{l}$ (plantain foufou with clear sauce: $\mathrm{FFB} / \mathrm{SC}$ ) and $0.89 \mathrm{~g} / \mathrm{l}$ (yam foutou with namoukou sauce: FI / SNA) while that of the rats who consumed the reference dish was $0.87 \mathrm{~g} / \mathrm{l}$. The urea contents of the blood of the rats were between 0.22 and $0.26 \mathrm{~g} / \mathrm{l}$. They were identical to that of the control rats $(0.26 \mathrm{~g} / \mathrm{l}) . \mathrm{The}$ rats which consumed the traditional dishes had creatinine contents between 6.83 (FFB / SC) and 8 mg / l (FI / SNA) while the controls had a creatinine content of $7.83 \mathrm{mg} / \mathrm{l}$. The uric acid contents of the rats fed with the Ivorian dishes varied between 22.5 and $26.0 \mathrm{mg} / \mathrm{l}$ while that of the control rats was $23.83 \mathrm{mg} / \mathrm{l}$. The total cholesterol levels in the rats accustomed to Ivorian dishes were between 1.51 and $1.75 \mathrm{~g} / \mathrm{l}$ while that of the rats having ingested the control dish was $1.69 \mathrm{~g} / \mathrm{l}$. The triglyceride values $(0.84$ to $1.02 \mathrm{~g} / \mathrm{l})$ were lower than that of the rats fed with the reference dish (1.05 $\mathrm{g} /$ l). Analysis of histopathological sections of the liver and of the kidney showed no organizational abnormalities of the tissues. The regular consumption of Ivorian local dishes ensures the proper functioning of the consumer's body.
\end{abstract}

Keywords - Traditional dishes, Ivorian, biochemical parameters, regulatory organs

\section{INTRODUCTION}

Food has always been the major concerns of human daily life [1]. This diet has the role of providing, in quantity and quality, nutrients for the harmonious functioning of the body, while helping to prevent diseases by excess and by default according to [2]. In addition, it plays a social, cultural and vital role. Therefore, it is essential to provide communities with adequate food that takes into account the quantity, quality and balance of food. Indeed, a balanced diet favorably influences nutrition in general and positively influences the body's natural aging, thereby improving the quality of life and reducing the incidence of certain diseases [3].

In addition, the industrial revolution has increased food availability and the abundance of calories made available to populations, with an increase in the energy intake attributed to lipids and a decrease in that attributed to carbohydrates [4]. This industrialization has strongly contributed to the installation of new diet habits of the populations, which have led to overfeeding. Some authors, such as [5], have argued that the food and nutritional transition has given rise to new, noncommunicable, slow and permissive diseases [6]. These nutritional changes have had adverse health consequences and can be regarded as public health problems. According to the [7], most traditional diets in developing countries were based on starchy staple foods, grains or roots and tubers, with a low proportion of lipids, often few animal products and high in fiber, especially in rural areas. A [8] to announce that traditional foods are very important components of the diet of people and the basis of their eating and nutritional habits. In Côte d'Ivoire [9], evaluated the nutritional effectiveness of three typical Ivorian dishes. In the world, in general and particularly in Côte d'Ivoire, very little research has been done in the direction of evaluating the impact of traditional dishes in preserving the integrity of the regulatory bodies of nutrition. 
The present study aims to assess the impact of regular consumption of the main Ivorian traditional dishes on growing rats to appreciate the state of functioning of vital organs, namely the liver and kidneys.

\section{MATERIALS AND METHODS}

\subsection{Materials}

The biological material of plant origin used consisted of four main Ivorian dishes, attiéké with red palm oil in a clear sauce (ATR / SC), white rice cooked in baouin sauce (RI / SBA), yam foutou with namoukou sauce (FI / SNA), plantain foufou with clear sauce (FFB / SC). The biological material of animal origin consisted of forty (40) growing Wistar strain rats. Technical equipment was also used for biological assays and for making histological sections. In addition, technical laboratory equipment was used to conduct the animal experiments.

\subsection{Methods}

\subsubsection{Selection of experimental dishes}

Following a family food consumption survey carried out in forty-four (44) localities in Côte d'Ivoire, the main traditional dishes were identified, based on their frequency of consumption by members of the households visited. Following this preliminary work, the plantain foufou with clear sauce (FFB / SC), the yam foutou with namoukou sauce (FI / SNA), white rice cooked in baouin sauce (RI / SBA) and attiéké with red palm oil in a clear sauce (ATR / SC), were selected for animal experimentation. The reference dish (control) was obtained according to [10] with modifications.

\subsubsection{Composition of experimental dishes}

The ash contents of the Ivorian traditional dishes selected were between $5.4 \%$ (ATR / SC) and 9.2 \% (FI / SNA) while the protein contents were between $12.62 \mathrm{~g} / 100 \mathrm{~g}$ DM (ATR / SC) and $14.34 \mathrm{~g} / 100 \mathrm{~g}$ DM (FI / SNA). The lipid contents varied from $4.43 \mathrm{~g} / 100 \mathrm{~g}$ M.S (FI / SNA) to $31.10 \mathrm{~g} / 100 \mathrm{~g}$ M.S (FFB / SC). However, their total carbohydrate contents ranged from $45.65 \mathrm{~g} / 100 \mathrm{~g}$ M.S (FFB / SC) to $69.01 \mathrm{~g} / 100 \mathrm{~g}$ M.S (FI / SNA). The experimental dishes had variable and statistically different biochemical compositions (Table 1). The control dish consisted of fishmeal (herring), cornflour, sugar, premix (vitamin and mineral supplement), agar agar, sunflower oil and water. Its protein content was $12.62 \%$ and provided an energy of $4279.07 \mathrm{kcal} / \mathrm{kg}$ (Table 2 ).

Table 1: Biochemical composition of Ivorian traditional experimental dishes

\begin{tabular}{lcccc}
\hline \multicolumn{1}{c}{ Ivorian dishes } & ATR/SC & RI/SBA & FI/SNA & FFB/SC \\
\hline Ash (\%) & $5.4 \pm 0.6^{\mathrm{c}}$ & $6.4 \pm 0.0^{\mathrm{b}}$ & $9.2 \pm 0.0^{\mathrm{a}}$ & $6.2 \pm 0.0^{\mathrm{b}}$ \\
Protein (\%) & $12.62 \pm 0.02^{\mathrm{d}}$ & $14.19 \pm 0.01^{\mathrm{b}}$ & $14.34 \pm 0.02^{\mathrm{a}}$ & $13.55 \pm 0.01^{\mathrm{c}}$ \\
Fat (\%) & $28.06 \pm 0.02^{\mathrm{c}}$ & $29.78 \pm 0.01^{\mathrm{b}}$ & $4.43 \pm 0.03^{\mathrm{d}}$ & $31.10 \pm 0.01^{\mathrm{a}}$ \\
Total carbohydrates (\%) & $48.91 \pm 0.59^{\mathrm{b}}$ & $47.64 \pm 0.03^{\mathrm{c}}$ & $69.01 \pm 0.05^{\mathrm{a}}$ & $45.65 \pm 0.01^{\mathrm{d}}$ \\
& & & & \\
Energy value (kcal/100 g MS) & $498.73 \pm 2.79^{\mathrm{c}}$ & $515.41 \pm 0.06^{\mathrm{b}}$ & $373.33 \pm 0.15^{\mathrm{d}}$ & $516.78 \pm 0.08^{\mathrm{a}}$
\end{tabular}

The values are the means of three determinations $(\mathrm{n}=3)$. On each line, the values assigned the same letters are not significantly different at the $5 \%$ threshold. ATR / SC: attiéké in red palm oil with clear sauce, RI / SBA: white rice cooked in baouin sauce, FI / SNA: yam foutou with namoukou sauce, FFB / SC: banana foufou plantain in clear sauce.

Table 2: Composition of the witness dish

\begin{tabular}{lccc}
\hline Inputs & Quantities $(\mathrm{g} / \mathrm{kg} \mathrm{MS})$ & Protein $(\%)$ & Energy $(\mathrm{kcal} / \mathrm{kg})$ \\
\hline Fishmeal & 176.9 & & \\
Cornflour & 758.1 & 12.62 & 4279.07 \\
Sugar & 9 & & \\
Premix & 1 & \\
Agar agar & 5 & \\
Sunflower oil & 50 & \\
Water (ml) & 1000 &
\end{tabular}

\subsubsection{Constitution of batches of rats and animal experiments}

The experimental study was carried out using 40 growing rats from the wistar strain, made up in five batches, consisting of eight rats. The model [11] was used to conduct this study. The rats were placed in individual metabolism cages with wire mesh bottoms. Every morning, between 7 a.m. and 8 a.m., each rat received 40 grams of the food intended for its 
batch. These dishes were made into a dough, using one liter of water at $100{ }^{\circ} \mathrm{C}$ for one kilogram of flour in the reconstituted dish. Water was served at will from a drinking trough and changed every two days. The experiment lasted 22 days, including 2 days for the rats adaptation and 20 days for the growth phase.

\subsubsection{Assay of blood biochemical parameters}

The automatic analyzer uses common methods of assaying biological parameters. The device has been programmed to take the various biological measurements. The device was zeroed with physiological water. The reagents were placed in the reagent compartment. The labeled samples were placed in the sample compartment at positions indicated on the screen.

\subsubsection{Rat blood collection and processing}

At the end of the experiment, the rats were sacrificed after anesthesia with ethyl urethane [12 - 13]. Blood samples were collected in dry tubes without anticoagulant. These tubes, submerged in an ice bucket, were taken to the medical analysis laboratory. These samples were centrifuged at $3000 \mathrm{rpm}$ for $10 \mathrm{~min}$ in a refrigerated centrifuge at $4^{\circ} \mathrm{C}$ [14 - 13]. The serum was collected in hemolysis tubes and stored in a freezer at $0^{\circ} \mathrm{C}$ before biochemical analyzes.

\subsubsection{Determination of glucose content}

The glycemia was assayed according to the enzymo-colorimetric test according to [15] and [16]. This test is based on the principle of the oxidation of glucose.

\subsubsection{Determination of blood uric acid content}

The uric acid content was determined by the enzymatic method [17].

\subsubsection{Determination of urea content}

This test was carried out by kinetic assay in which the onset of the reaction is linear within a defined time interval [18]. The initial decrease in optical density at $340 \mathrm{~nm}$ is proportional to the urea concentration in the sample.

\subsubsection{Determination of blood creatinine content}

The serum creatinine was assayed according to [19]. This test is based on a colorimetric method. Creatinine reacts with picrate in alkaline solution to form a yellow-orange colored complex. The reaction product was measured by a spectrophotometer at $492 \mathrm{~nm}$.

\subsubsection{Determination of total blood cholesterol content}

Cholesterolemia was determined according to the enzymo-colorimetric test [15]. Cholesterol and its esters are separated from lipoproteins by detergents.

\subsubsection{Determination of HDL cholesterol content in the blood}

The supernatant obtained after centrifugation contains high density lipoproteins (HDL), the cholesterol of which is determined by cholesterol oxidase [15].

\subsubsection{Determination of blood triglyceride content}

The determination of circulating triglycerides in the blood was carried out according to the enzymo-colorimetric test of [20]. In principle, triglycerides are hydrolyzed into glycerol and free fatty acids.

\subsection{Histological Techniques}

The different stages of the classical histology technique were applied according to the method described by [21]. Thus, the organ portions were fixed in $10 \%$ formalin for 5-7 days. Each part was accompanied by an identification label bearing the date of collection, the name of the organ and its weight. The organ trapped in the paraffin block was cut into a series of $7 \mu \mathrm{m}$ thick sections using a microtome. Observations were made with a microscope.

\subsection{Statistical Analysis}

The data presented as the mean were obtained by analysis of variance using a one-way ANOVA, using IBM SPSS STATISTICS version 19.0 software. The comparison of the mean values was made using the Duncan's test at the significance level of $5 \%$.

\subsection{Results}

\section{RESULTS AND DISCUSSION}

\subsubsection{Blood sugar}

The blood sugar levels of the rats that have consumed the Ivorian traditional dishes and the control studied varied from $0.79 \mathrm{~g} / 1$, for the rats that have ingested banana foufou in clear sauce (FFB / SC), to $0.89 \mathrm{~g} / 1$ for rats subjected to yam foutou with namoukou sauce (FI / SNA). That of the rats which consumed the reference food was $0.87 \mathrm{~g} / 1$. The blood 
glucose levels of the rats that consumed the different foods were statistically identical to that of the rats fed with the reference meal except that of the rats consuming the FFB / SC (Figure. 1).

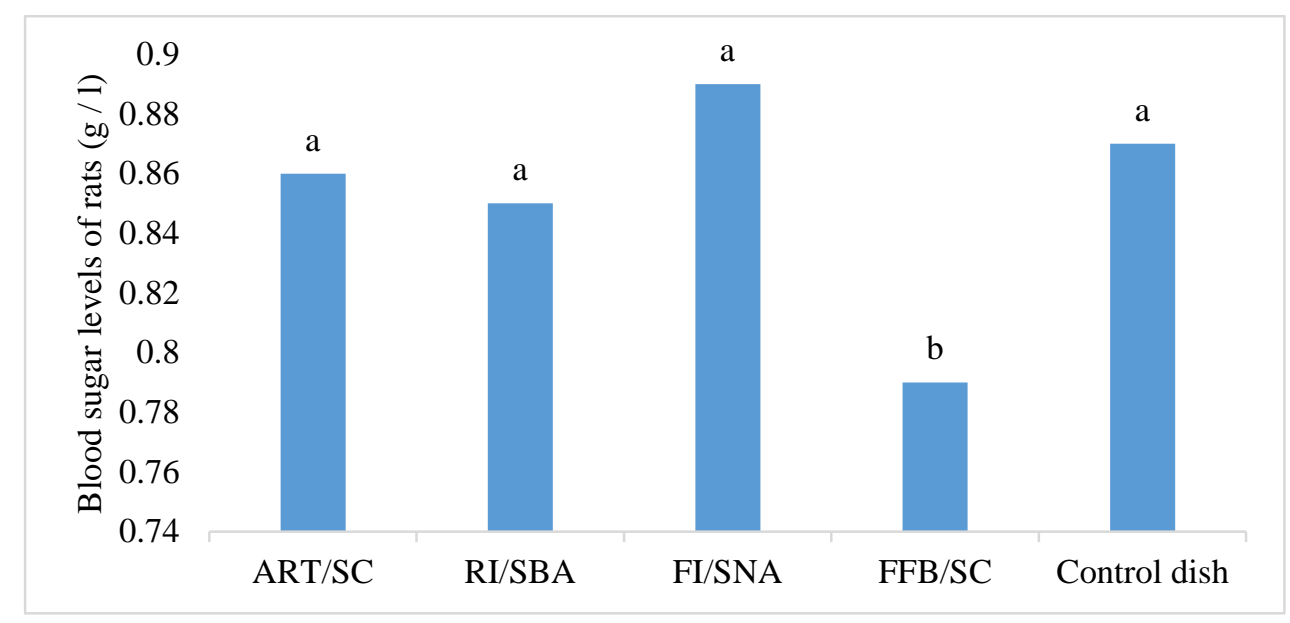

\subsubsection{Urea, creatinine, uric acid}

Figure 1: Mean value of blood glucose in rats

Table 3 shows the urea, creatinine and uric acid contents in the blood of rats fed with Ivorian meals. The urea contents were between $0.22 \mathrm{~g} / 1$ (FFB / SC) and $0.26 \mathrm{~g} / 1$ (FI / SNA). The rats who ingested attiéké with red palm oil in clear sauce had a uremia equal to $0.23 \mathrm{~g} / 1$ while that of the rats who consumed white rice cooked in baouin sauce was $0.24 \mathrm{~g} / 1$, whereas those fed with yam foutou in namoukou sauce had a uremia of $0.26 \mathrm{~g} / 1$. All these levels were statistically equal to that of the rats which consumed the reference food $(0.26 \mathrm{~g} / 1)$.

The blood creatinine levels of the rats which consumed the Ivorian traditional dishes were between $6.83 \mathrm{mg} / 1$ (FFB / $\mathrm{SC}$ ) and $8 \mathrm{mg} / 1$ (FI / SNA). The blood creatinine content of rats consuming attiéké in red oil (ATR / SC) was $7.33 \mathrm{mg} / 1$ and that of their congeners having ingested white rice cooked in baouin sauce (RI / SBA) was $7.5 \mathrm{mg} / 1$. The rats ingesting the control meal had a creatinemia equal to $7.83 \mathrm{mg} / 1$. The creatinemia of the rats showed no significant difference regardless of the food consumed. The blood uric acid values of the rats fed the food varied between $22.5 \mathrm{and} 26.0 \mathrm{mg} / 1$ and that of the rats that consumed the reference food was $23.83 \mathrm{mg} / 1$. Analysis of these values shows that the blood uric acid levels in rats fed the different foods studied were statistically identical to those in rats that consumed the reference food.

Table 3: Urea, Creatinine and Uric Acid

\begin{tabular}{lccc}
\hline Dishes & Urea $(\mathrm{g} / \mathrm{l})$ & Creatinine $(\mathrm{mg} / \mathrm{l})$ & Uric acid (mg/l) \\
\hline ATR/SC & $0.23 \pm 0.06^{\mathrm{a}}$ & $7.33 \pm 0.8^{\mathrm{a}}$ & $26.0 \pm 3.63^{\mathrm{a}}$ \\
RI/SBA & $0.24 \pm 0.06^{\mathrm{a}}$ & $7.5 \pm 0.7^{\mathrm{a}}$ & $22.50 \pm 2.25^{\mathrm{c}}$ \\
FI/SNA & $0.26 \pm 0.05^{\mathrm{a}}$ & $8 \pm 0.9^{\mathrm{a}}$ & $24.50 \pm 6.18^{\mathrm{b}}$ \\
FFB/SC & $0.22 \pm 0.02^{\mathrm{a}}$ & $6.83 \pm 0.78^{\mathrm{a}}$ & $25.0 \pm 7.04^{\mathrm{ab}}$ \\
CONTROL DISH & $0.26 \pm 0.02^{\mathrm{a}}$ & $7.83 \pm 0.75^{\mathrm{a}}$ & $23.83 \pm 2.48^{\mathrm{b}}$ \\
\hline
\end{tabular}

Each value is the mean \pm standard deviation of eight rats $(n=8)$. In each column, the values assigned the same letters are not significantly different at the $5 \%$ threshold. ATR / SC: attiéké with red palm oil with clear sauce, RI / SBA: white rice with baouin sauce, FI / SNA: yam foutou with namoukou sauce, FFB / SC: banana foufou with the clear sauce.

\subsubsection{Lipid profile}

The total blood cholesterol levels of the rats were $1.51 \mathrm{~g} / 1$ for the rats consuming attiéké with red palm oil in clear sauce (ART / SC), $1.58 \mathrm{~g} / 1$ for those having ate the yam foutou with namoukou sauce (FI / SNA). Those of the rats subjected to banana foufou in clear sauce (FFB / SC) and to white rice cooked in baouin sauce were respectively $1.62 \mathrm{~g} / 1$ and $1.75 \mathrm{~g} / 1$. As for the rats fed with the control food, they exhibited a total cholesterol content of $1.69 \mathrm{~g} / 1$. The blood HDL cholesterol levels in the rats were $0.52 \mathrm{~g} / 1$ for the rats fed yam foutou in namoukou sauce (FI / SNA) and those who 
consumed the control dish. Rats ingesting banana foufou in clear sauce (FFB / SC) and those fed attiéké in red oil in clear sauce (ART / SC) had the same blood HDL cholesterol content of $0.53 \mathrm{~g} / 1$. The HDL cholesterol content of $0.55 \mathrm{~g} / 1 \mathrm{in}$ the blood corresponds to that of the rats which consumed white rice cooked in baouin sauce (RI / SBA). The levels of HDL cholesterol in the blood were statistically identical. The blood triglyceride content of the rats that consumed the red palm oil attiéké in clear sauce (ART / SC) was $0.87 \mathrm{~g} / 1$. That of rats fed white rice cooked in baouin sauce (RI / SBA) was 0.84 $\mathrm{g} / 1$ while that of rats consuming banana foufou in clear sauce (FFB / SC) was $0.86 \mathrm{~g} / 1$. The blood triglyceride content of the rats fed the control meal was $1.05 \mathrm{~g} / 1$. The blood triglyceride values of the rats ingesting Ivorian traditional dishes were lower than that of their congeners fed the control dish, except that of the rats having consumed the yam foutou with namoukou sauce (1.02 g / 1) which was statistically identical to that of control rats.

Table 4: Lipid balance of rats after eating the food

\begin{tabular}{lccc}
\hline Dishes & Total Chol $(\mathrm{g} / \mathrm{l})$ & HDL chol $(\mathrm{g} / \mathrm{l})$ & Triglycerides $(\mathrm{g} / \mathrm{l})$ \\
\hline ATR/SC & $1.51 \pm 0.05^{\mathrm{c}}$ & $0.53 \pm 0.03^{\mathrm{a}}$ & $0.87 \pm 0.06^{\mathrm{b}}$ \\
RI/SBA & $1.75 \pm 0.06^{\mathrm{a}}$ & $0.55 \pm 0.02^{\mathrm{a}}$ & $0.84 \pm 0.05^{\mathrm{b}}$ \\
FI/SNA & $1.58 \pm 0.06^{\mathrm{bc}}$ & $0.52 \pm 0.04^{\mathrm{a}}$ & $1.02 \pm 0.03^{\mathrm{a}}$ \\
FFB/SC & $1.62 \pm 0.03^{\mathrm{bc}}$ & $0.53 \pm 0.02^{\mathrm{a}}$ & $0.86 \pm 0.07^{\mathrm{b}}$ \\
CONTROL DISH & $1.69 \pm 0.07^{\mathrm{a}}$ & $0.52 \pm 0.03^{\mathrm{a}}$ & $1.05 \pm 0.1^{\mathrm{a}}$ \\
\hline
\end{tabular}

Each value is the mean \pm standard deviation of eight rats $(\mathrm{n}=8)$. In each column, the values assigned the same letters are not significantly different at the $5 \%$ threshold. ATR / SC: attiéké with red palm oil with clear sauce, RI / SBA: white rice with baouin sauce, FI / SNA: yam foutou with namoukou sauce, FFB / SC: banana foufou with the clear sauce

\subsubsection{Histology and histopathology of rat liver}

The appearance of the hepatic parenchyma observed in the rats fed with the reference food (Figure 2A) is the same as that observed in the rats having consumed attiéké with red palm oil in a clear sauce (Figure 2B), yam foutou with namoukou sauce (Figure 2C), white rice cooked in baouin sauce (Figure 2D) and plantain foufou with clear sauce (Figure 2E). The sections of the liver show normal liver parenchyma.

\subsubsection{Histology and histopathology of rat kidneys}

The results of the kidney sections show that the kidney tissue is made up of glomeruli and renal tubules which are specific structures of the cortex. Examination of the glomerulus shows that it is well bounded by Bowman's capsule. The glomerular chamber is demarcated and the capillary platoon is visible. Around the glomerulus, the renal tubules are visible with distinct contours and individualized bordering cells. The structure of the medullary zone indicates the presence of collecting tubes, namely the proximal convoluted tube and the distal convoluted tube. The sections observed show the same structure as that of normal renal tissue of the cortex and medulla. The observations showed no abnormalities or changes in the kidney tissue of the rats that consumed the control dish (Figure 3A). These same observations were made with the kidney tissues of rats fed with attiéké in red palm oil in clear sauce (Figure 3B), yam foutou in namoukou sauce (Figure 3C), rice white cooked in baouin sauce (Figure 3D) and plantain foufou in clear sauce (Figure 3E). 

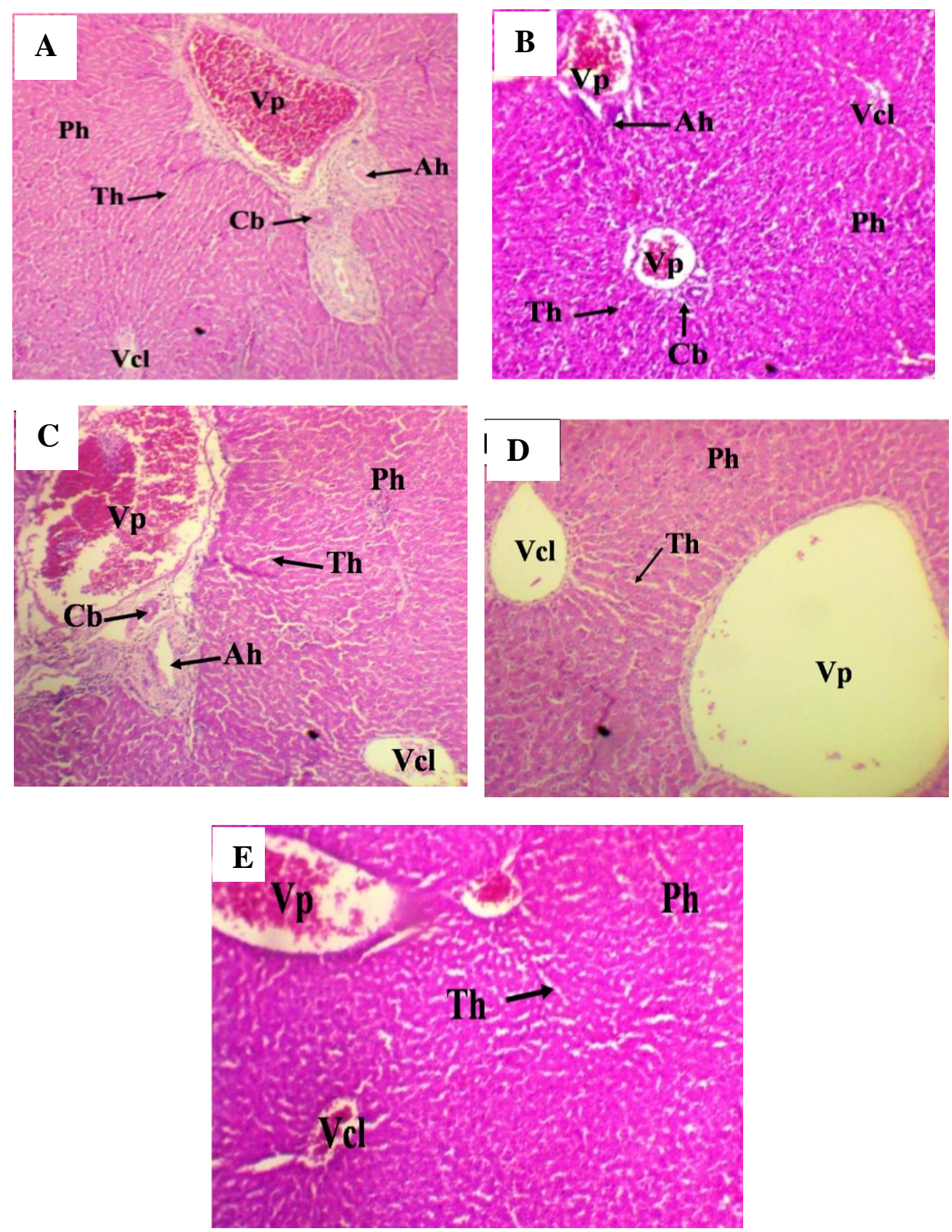

Figure 2: Histopathological sections of rat liver (G x 100; Hemalum eosin: HE) Ah: hepatic artery; $\mathrm{Cb}$ : Gallic canaliculus; $\mathrm{Ph}$ : hepatic parenchyma;

Th: Hepatocyte spans; Vcl: Centrilobular vein; Vp: branch of the portal vein 

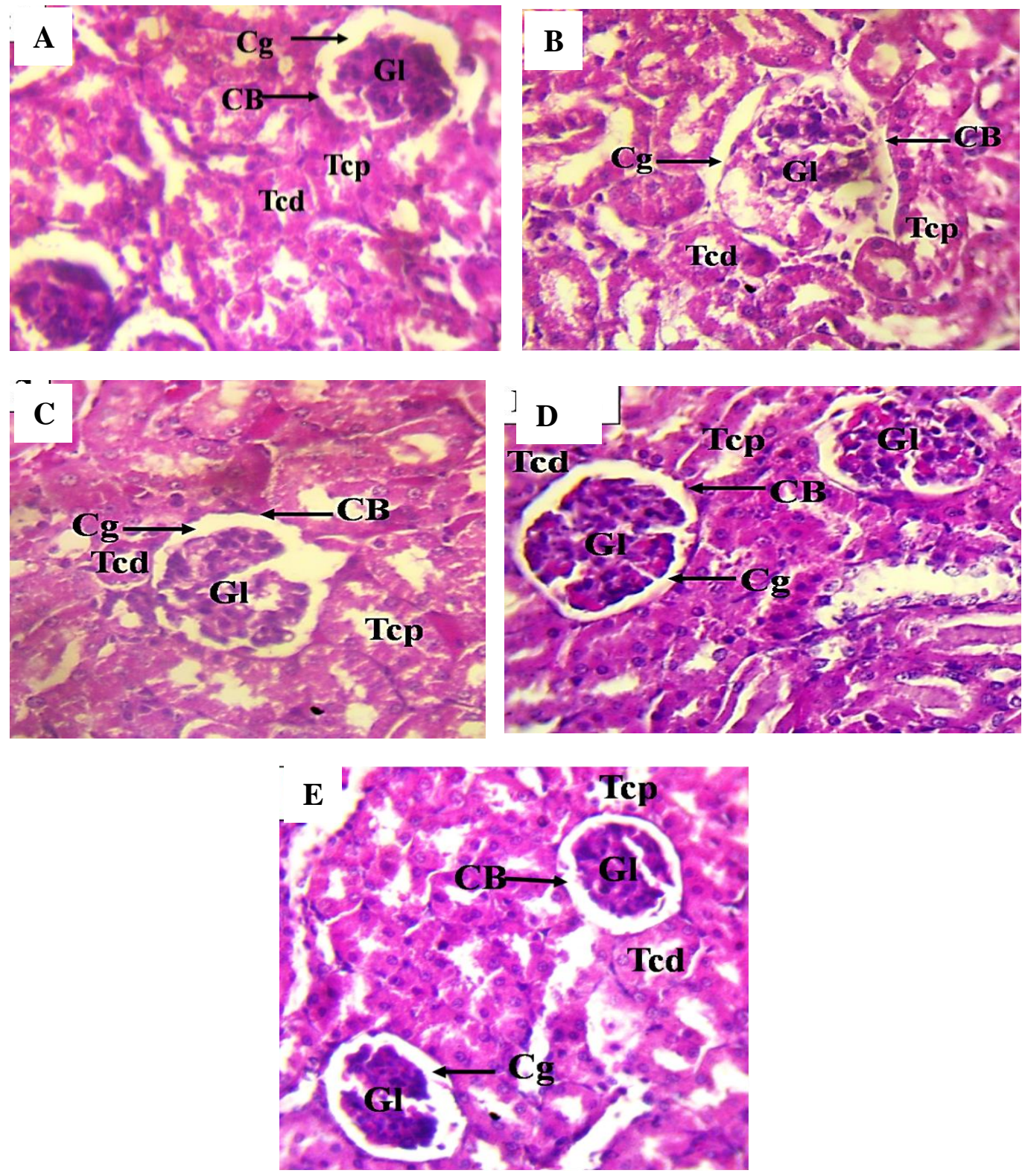

Figure 3: Histopathological sections of rat kidney ( $\mathrm{G} x$ 400; Hemalum eosin: HE)

CB: Bowman's capsule; Cg: glomerular chamber; Gl: glomerulus;

Tcd: distal convoluted tube; Tcp: proximal convoluted tube

\subsection{Discussion}

The objective of this study was to assess the impact of the consumption of the main Ivorian traditional experimental dishes on biochemical parameters of the blood, liver and kidneys in growing rats. The value of assaying biochemical parameters in the blood in nutrition studies implies that the excess or deficit in the production of a substance synthesized by an organ is indicative of its dysfunction [22]. It is for this reason that blood sugar, blood uric acid, uremia, serum creatinine, blood triglycerides and blood cholesterol were tested. The blood sugar levels of the rats that consumed Ivorian traditional dishes were between $0.79 \mathrm{~g} / 1$ and $0.89 \mathrm{~g} / 1$. The glycemia of the rats having consumed the differences in glycemia recorded could be explained by the influence of the glycemic reaction by factors such as the metabolism specific to each individual, the balance between carbohydrate and non-carbohydrate nutrients and the time of the blood sample in relation to the time of food ingestion [23]. When blood sugar levels are chronically elevated, material component synthesis becomes excessive and hepatic fibrosis may develop [24 - 25]. In contrast, low blood sugar could be called hypoglycemia. 
Consumption of the main Ivorian traditional dishes under these experimental conditions did not disturb the blood sugar levels in the rats.

The blood uric acid contents of the rats which consumed the Ivorian dishes are close to that of the rats which were fed with the control dish. An increase in the mean value of blood uric acid is thought to indicate renal failure in rats [13].

The blood urea values of the rats subjected to the Ivorian traditional meals were all normal because they were statistically identical to that of the rats fed with the reference meal $(0.26 \mathrm{~g} / 1)$. Urea comes from the breakdown of proteins and is excreted mainly by the kidneys. Its content reflects the overall functioning of the kidneys [26 - $27-28]$. These results show that the proteins were well digested.

The creatinemia of the rats, varying from 6.83 to $8 \mathrm{mg} / 1$, was normal and did not present a significant difference whatever the Ivorian traditional dish consumed by the rats. The blood creatinine level is an indirect marker of renal function [29]. Its production is relatively constant in an individual and depends only on its muscle mass.

Changes in the level of creatinine in the blood may suggest the formation of renal cannulas [30 - 31 - 32]. It is eliminated only by the kidneys through the glomerulus (Pierre et al., 2010). Thus, a low production of creatinine indicates an abnormality in the renal physiology of these animals [33]. The similarity between the creatinine levels of the rats consuming the traditional dishes and the control dish indicates the maintenance of good physiology and proper functioning of the organs essential to the maintenance of human life [31].

The total blood cholesterol levels in the rats which consumed the various Ivorian traditional dishes were normal, because they were similar to that of the rats which ingested the control dish. The levels of HDL cholesterol in the blood were identical and normal, regardless of the food ingested. The normal blood cholesterol values of rats having consumed Ivorian dishes help to explain the absence of disturbance in cholesterol metabolism [34].

Indeed, these diets have low contents of lipids and saturated fatty acids. The inclusion of saturated fatty acids in the diet above a certain threshold is the cause of hypercholesterolemia in rats [35 - 36]. Most of the blood triglyceride values of rats fed Ivorian traditional foods were lower than those of rats accustomed to the control food. The blood triglyceride value of rats fed yam foutou with namoukou sauce was identical to that of rats ingesting the control dish. These results could be explained by the fact that the triglyceride content results from the balance between the production of lipoproteins rich in triglycerides and their peripheral purification. In other words, excess circulating triglycerides may be linked to excess production and / or poor purification [37].

Results observed with histological and histopathological sections of the liver and kidneys of the rats revealed no dysfunction of the liver and kidneys. These results are consistent with the assays of the blood biochemical parameters. The results could be explained by the absence of substances that are difficult to metabolize in these dishes [11], which would impose an increased activity of the liver and kidneys. Any additional activity would cause adaptations or modifications or even alterations in said organs. The proper functioning of the channels and the exchange system is evidenced by the absence of abnormalities in the sections of the kidneys and liver of the rats. Our results corroborate those of [26]. The latter concluded that the physiology of the rat kidneys was good. This conformity of results makes it possible to say that the kidneys of the rats fed with the Ivorian traditional dishes functioned without damage and their integrity would be preserved. It appears that the consumption of the Ivorian traditional dishes evaluated cannot be directly indexed as the cause of an anomaly in the organs evaluated. Hence, Ivorian traditional dishes have good nutritional qualities. Therefore, they can be advised, in order to ensure and maintain good health and prevent various pathologies related to nutrition.

\section{CONCLUSION}

The study revealed that the biological examinations carried out showed normal values in blood glucose, blood uric acid, uremia, creatinemia, cholesterolemia and triglyceridemia, in order to ensure and maintain good health and prevent various pathologies related to nutrition. Histological and histopathological examination of the liver and kidneys in rats, under the diet of Ivorian traditional dishes, showed healthy organs. The ingestion of the main Ivorian traditional dishes, in accordance with the principles of a good diet, does not affect the liver or the kidneys.

\section{REFERENCES}

[1] Esnouf C, Russel M, Bricas N (Coords), duALIne - durabilité de l'alimentation face à de nouveaux enjeux. Questions à la recherche, Rapport Inra-Cirad (France), 236 p, 2011.

[2] Harris L E, Nutrition research. Techniques for domestic and wilds animals, Vol 1, pp. 843-851, 1970. 
[3] Agence de Sante Publique du Canada, Programme national intégré de prévention de maladies non transmissibles (CINDI). Gouvernement du Canada, 2003. [En ligne] : http://www.phac-aspc.gc.ca/ ccdpc-cpcmc/cindi/index_f.htmL. Consulté le 28/12/2016.

[4] Swinburn B A, Sacks G, Hall K D, McPherson K, Finegood D T, Moodie M L, Gortmaker S L, The global obesity pandemic: shaped by global drivers and local environments, The Lancet, vol 378 n ${ }^{\circ}$ 9793, pp. 804-814, 2011.

[5] Popkin B M, Gordon-Larsen P, The nutrition transition: worldwide obesity dynamics and their determinants. Inter. J. Obes., vol $28 n^{\circ} 2-9,2004$.

[6] Padilla M, Alimentation et évolution de la consommation. In : Les futurs agricoles et alimentaires en Méditerranée. (P. d. S. Po, ed.), CIHEAM, Montpellier. p. 149-167, 2008a.

[7] WHO, World Health Organisation Multicentre Growth Reference Study Group. WHO child standard based on length/heigth, weigth and age. Acta peadiatre, vol 5, pp. 76-85, 2004.

[8] Dagher S M, Traditional foods in the near east. FAO: Food and Nutrition paper, vol 50, Rome, 161 p, 1991.

[9] Dally T, Méité A, Kouamé K G, Bouafou K G M, Kati-Coulibali S, Efficacité nutritionnelle de trois mets ivoiriens : cabatoh à la sauce dah au nord; foutou d'igname à la sauce gouagouassou au centre ; riz cuit à la sauce graine à l'ouest. J. Appl: Biosci., vol 33, 2084-2090, 2010.

[10] Garcin H, Higueret P, Amoikon K, Effect of large dose of retinol or retinoid acid on thyroid hormones in the rats. Ann. Nutr. Metab., vol 28, pp. 92-100, 1984.

[11] Adrian J, Rabache M, Fragne R, Techniques d'analyse nutritionnelle. In Principes de Techniques d'Analyse. Ed Lavoisier TEC \& DOC : Paris ; pp. 451-478, 1991.

[12] Méité A, Kouamé K G, Kati-Coulibaly S, Offoumou A M, 2008. Etude de la valeur nutritionnelle du pain normal et des pains composites contenant de la farine de graine de Citrillus lanatus (Cucurbitacées). Soc. Roy. Sci. Liège, vol 77 , pp. 80-103, 2008.

[13] Amoikon K E, Kouamé K G, Kati-Coulibaly S, Effect of chromium and proteins diets in rats. Inter. J. PAES, vol 2 n 2, pp. 1-8, 2012.

[15] Trinder P, Determination of blood glucose using 4 aminophenazone as oxygen acceptor. J. clin. Path., 22: 246-255, 1969.

[16] Dingeon B, Ferry J P, Roulet A, Automatic assay of blood sugar by Trinder's Method, Annal. Biol. Clin., vol 33, pp. 3-13, 1975.

[17] Tietz N W, Text book of clinical chemistry, 3 rd Ed. C. A. Burtis, E. R., Ashwood, W. B. Saunders, pp. 652-1250, 1999.

[18] Kaplan L A, Szabo L L, Orpherin E K, Clinical chemistry : Interpretation and Techniques. 3rd edition Lea \& Febliger, Philadelphia, pp. 112-231, 1988.

[19] Henry R J, Clinical chemistry principles and techniques. 2nd Edition, Harper and Row, 543 p, 1974.

[20] Young D S, Pestaner L, Giberman V, Effects of drugs on clinical laboratory test. J. Clin. Chem., vol $21 \mathrm{n}^{\circ} 5$, pp. 10432, 1975.

[21] Martoja R, Martoja P M, Initiation aux techniques de l'histologie animale. Edition Masson et Cie, Paris, 345 p, 1967.

[22] Pellet P L, Young V R, Nutritional evaluation of protein foods. Edited by Peter L. Pellet and Vermon R. Young. The United Nations University, 323 p, 1980.

[23] Foster-Powell K, Brand-Miller J, International tables of glycaemic index. Amer. J. Clin. Nutr., vol 62, pp. 871-893, 1995. 
[24] Gressner A M, Bachem M G, Cellular communications and cell-matrix interactions in the pathogenesis of fibroproliferative diseases : liver fibrosis as paradigm. Ann. Biol. Clin., vol 52, pp. 205-226, 1994.

[25] Friedman S L, Mechanisms of hepatic fibrogenesis. Gastroenterology, vol 134, pp. 1655-1669, 2008b.

[26] Abuelo J G, Renal failure caused by chemicals, foods, plants, animal venoms and misuse of drug. An Overview. Arch Inter. Med., vol 150 n³, pp. 505-510, 1990.

[27] Mogensen C E, Keane W F, Bennett P H, Prevention of diabetic renal disease with special reference to microalbuminuria. Lancet, vol 346, pp. 1080-1084, 1995.

[28] Kouakou E K V, Bouafou K G M, Méité A, Kouame K G, Kati- Coulibaly S, Farine de sevrage commerciale ANAGOBAKA : quels risques pathologiques dans le régime du rat en croissance ? Inter. J. Biol. Chem. Sci., vol 10 nº 1 , pp. 167-174, 2016.

[29] Séronie S, Vivien M, Galteau M, Carlier M C, Hadj A, Dosage de la créatininémie en 2003 : état des lieux analytiques et essai de standardisation de l'étalonage. Ann. Biol. Clin., vol 62, pp. 165-175, 2004.

[30] Williams S R, Essentials of nutrition diet therapy, 6th Edition Mosby, 521 p, 1994.

[31] Bankir L, Urea and the kidney, in The Kidney (5th Edition), edited by Brenner B. M., Rector F. C. J. R., Philadelphia, W. B. Saunders Company, pp. 571-606, 1996.

[32] Brunette M G, Régulation du métabolisme calcique. In: Offenstadt G, Brunette M. G. Désordres acido-basiques et hydroélectrolytiques. Paris, Arnette Blackwell, pp. 294-312, 1997.

[33] Coffi T, Ahissou H, Gouthon P, Laleye A, 2014. Etude de l'activité antihypertensive d'une association de plantes (Schrankia leptocarpa, Garcinia kola et Ocimum americanum) chez le rat Wistar. Inter. J. Biol Chem. Sci., vol 8 no 6, pp. 2685-2695.

[34] Seyrek K, Yenisey C, Serter M, Kargin K F, Ulutas P A, Bardakcioglu H E, Effects of dietary with vitamin C supplementation on some serum biochemical parameters of laying Japanese quails exposed to heat stress $\left(34.8^{\circ} \mathrm{C}\right)$. Rev. Med. Vétér., vol 155 no 6, pp. 339-342, 2004.

[35] Lutz M, Cortez J, Vinet R, Dietary fats and cholesterol supplementation effects on aortic and lipid response in rats. J. Nutr. Bioch., vol 5, pp. 446-450, 1994.

[36] Zulet M A, Barbe A, Garcin H, Higueret P, Martinez J A, Alteration in carbohydrate and lipid metabolism induced by a diet rich in coconut oil and cholesterol in a rat model. J. Amer. Col. Nutr., vol 18, pp. 36-42, 1999.

[37] Craplet C H, Badevant A, Hypertriglycéridémie majeure, Cahier de nutrition et Diététique, vol 2, pp. 149-151, 1985. 